ikke er tale om en slags forlenget pubertet for individer som henfaller til slik form for kriminalitet i 17-18 års alderen. Det virker som om de fremdeles opptrer etter klubbalderens m $\phi$ nster og ikke som sine jevnaldrende, hvis opptreden i denne alder er mer selvstendig og innriktet på en eller to venner.

VI. En har i det foregående reist atskillig flere spørsmål enn en har kunnet svare på. Og det har da også nettopp vært hensikten.

Enhver som har arbeidet med kriminologiske spørsmål vil vite at for de aller fleste kriminelle og asosiale individers vedkommende synes deres problemer å ha sin rot tilbake $\mathrm{i}$ barneog ungdomsårene. Dette er ikke noe nytt. Konsekvensen av dette synes klar nok når det gjelder såvel den teoretiske kriminologi som den praktiske kriminalpolitikk, nemlig at det ikke finnes noe viktigere og mer fruktbart arbeidsfelt enn nettopp disse aldersgrupper.

Knut Sveri.

\title{
The Institute for the Study and Treatment of Delinquency.
}

Av bitr. stadsfiskal KLAS LITHNER.

Ovanstående institution (nedan kallad ISTD) startade år 1931 på initiativ av en kvinnlig läkare, Dr Grace Pailthorpe. Dess uppgift var dels att verka genom medicinsk, psykiatrisk och psykologisk behandling av brottslingar och dels att samtidigt bedriva vetenskaplig forskning inom kriminologin. Den förra uppgiften handhades av den samtidigt upprättade och av ISTD skötta Portman Clinic. Allt arbete skedde på frivillig basis och för att kunna avlöna sina medhjälpare var ISTD beroende av medlemsavgifter och donationer. Klinikens personal handhade undersökning och behandling av ett stort antal brottslingar, som hänvisats dit antingen genom att olika Magistrate's Courts i London givit dem villkorlig dom med föreskrift därom eller av läkare eller som själva uppsökt kliniken. Genom the National Health Service Act 1948 nationaliserades kliniken. Den arbetar fortfarande på samma sätt men nu i större skala, då dess personal numera är fast avlönad. ISTD, som fortsätter sin verksamhet liksom förut, utgiver sedan 1950 The British Journal of Delinquency, vars redaktionskommitté består av psykiatern Edward Glover, kriminologen Hermann Mannheim och psykologen Emanuel Miller.

ISTD har vidare startat en mindre, vetenskaplig grupp, som sammanträder varannan månad för diskussion av vetenskapliga problem 
under Mannheims ordförandeskap. Institutets medlemmar utgöras i huvudsak av jurister och läkare, jämte representanter för andra berörda grupper samt ett antal intresserade lekmän. ISTD bedriver även propagandaverksamhet $\mathrm{i}$ form av kurser och föreläsningar för Magistrates (lekmannadomare), psykiater, lärare och andra grupper.

ISTD har numera enligt sina stadgar följande uppgifter:

1) att igångsätta och befordra vetenskaplig forskning angående brottslighetens orsaker och förebyggande,

2) att samordna och sammanställa pågående vetenskaplig forskning angående nämnda företeelser,

3) att bereda möjligheter till teoretisk och praktisk utbildning av universitetsstuderande, lekmannadomare, "probation officers" och lärare $\mathrm{i}$ vetenskapliga studier av brottsligheten,

4) att åstadkomma samarbete mellan alla organisationer som syssla med liknande arbete över hela världen och i sista hand åstadkomma en internationell organisation,

5) att befordra diskussion och att uppfostra den allmänna opinionen rörande dessa frågor genom publikationer och på annat sätt,

6) att åstadkomma observationscentra för studium och behandling av brottslingar och

7) att utgiva en vetenskaplig tidskrift samt böcker och broschyrer rörande dessa frågor.

ISTD har tidigare som forskningsassistenter haft anställda de båda sociologerna Dr Tadeusz Grygier och W. Litauer. Båda ha emellertid på grund av de ekonomiskt osäkra villkoren måst övergå till annan verksamhet, vadan det vetenskapliga arbetet nu praktiskt taget ligger nere. Om ett begärt större anslag från en stiftelse beviljas, ämnar man göra en stor undersökning angående kvinnliga butikstjuvar (shoplifters).

Följande skrifter ha publicerats av ISTD under åren 1941-1957:

E. Glover: The psycho-pathology of prostitution.

- : The social and legal aspects of sexual abnormality.

H. Mannheim och J. Spencer: Problems of Classification,

Psychology and Criminal procedure (utgiven av en kommitté inom ISTD).

G. Gardiner, E. Glover och H. Mannheim: Capital Punishment.

M. Woodward: Low intelligence and delinquency.

E. Glover: The problem of homosexuality.

T. V. N. Gibbens och A. Walker: Cruel parents.

W. Litauer: Juvenile Delinquents in a Psychiatric Clinic.

Samtliga skrifter äro av mindre omfång.

Till grund för artikeln ligga upplysningar från institutets ordförande, Lord Chorley, och dess sekreterare, Miss Eve Saville. 